\title{
Argumentation and Aggression: About Maps and Poems in the Russian-Ukrainian Conflict ${ }^{1}$
}

\author{
Holger Kuße \\ Technische Universität Dresden, Institute of Slavonic Studies
}

\begin{abstract}
Argumentation as a function of human communication, and aggression as a feature of communicative behaviour, seem to be contrary to each other. Argumentation should be understood as the regulation of dissent based on rational arguments, whereas aggression can be seen as the manifestation and intensification of dissent. But the boundaries between rationality and irrationality, as well as between the regulation and the manifestation of dissent are often vague. Therefore, not only hate speech but also seemingly rational argumentation can be motivated by aggression and can lead to aggression. In the present study, this intertwinedness of argumentation and aggression is shown in the current Russian-Ukrainian conflict, where we can find the use of aggressive theses, reasons, and aggressive arguments in different semiotic and textual expressions: not only in political statements, but also in poetry and in multimodal forms like political maps. Combining argumentation theory with a case study of aggressive argumentation in the Russian-Ukrainian conflict, the paper presents several forms of intertwinedness of argumentation and aggression. The research is mainly based on maps as a type of popular geopolitics, in which the aggressive thesis of the non-existence of Ukraine is provided. The study also considers the poeto-political war around Anastasiia Dmytruk's poem "Nikogda my ne budem brat'iami" ("Never ever we will be brothers"). Responses to Dmytruk's thesis provoke not only disagreement but also negative and positive-negative agreement, which means that the opponent agrees with the thesis but rejects the reasons of the argument, or s/he agrees with the thesis and the reasons but evaluates them in a contradictory way. Whereas the analysis of maps shows mainly the performing of aggressive theses, the analysis of the poeto-political war highlights how reasons are provided in an aggressive communication frame.
\end{abstract}

Keywords: argumentation, argument, aggression, aggressive argumentation, Russian-Ukrainian conflict, political maps, Anastasiia Dmytruk, political poetry.

\footnotetext{
1 This research is based on a lecture on April 5, 2018, co-organized by the Canadian Institute of Ukrainian Studies and the Department of Modern Languages and Cultural Studies at the University of Alberta. It was carried out in the framework of the trilateral international project: "Aggression and Argumentation. Conflict Discourses and Their Linguistic Negotiations" ("Aggression und Argumentation. Konfliktdiskurse und ihre sprachliche Verhandlung") supported by the German funder of basic research Volkswagen Stiftung. I thank Alla Nedashkivska for her commentaries and corrections.
} 


\section{ABOUT THE INTERTWINEDNESS OF ARGUMENTATION AND AGGRESSION}

$\mathrm{W}$

hat are the relations between argumentation and aggression? To what degree do they overlap, or do they overlap at all? On the one hand, it is easy to identify contradictions between argumentation and aggression. Argumentation for instance is rational, and it attempts to be "a very logical way of discussing or debating an idea" ("Argumentation"). On the contrary, aggression is emotional and irrational. Argumentation should be dialogical, whereas aggression is rather monological. Argumentation is open-ended. Aggression is based on firm opinions. Last, argumentation is a "special sort of disagreement-regulating mechanism," while aggression is a manifestation of dissent and hostility (van Eemeren et al. 25). On the other hand, there is evidence for the agonal character of argumentation and for arguments based on aggression. It is probably no coincidence that the bestknown conceptual metaphor in Lakoff and Johnson's famous book Metaphors We Live by is ARGUMENT IS WAR. Actively used linguistic metaphors, cited by Lakoff and Johnson, instantiate this concept:

Your claims are indefensible.

He attacked every weak point in my argument.

His criticisms were right on target.

I demolished his argument.

I've never won an argument with him.

You disagree? Okay, shoot!

If you use that strategy, he'll wipe you out.

He shot down all of my arguments. (4)

A couple of years before Lakoff and Johnson, Norwegian philosopher Arne Naess called argumentation a tug of war and illustrated it by a central, strong line, with some longer and some shorter lines beside it, that symbolize different reasons for contradictory positions: $\mathrm{F}_{0}$ and Not- $\mathrm{F}_{0}$, illustrated in Figure 1. (The drawing can be found in the complete German translation from Norwegian, but not in the shortened English version.)

Figure 1: Argumentation as a tug of war by Arne Naess (Naess 148)

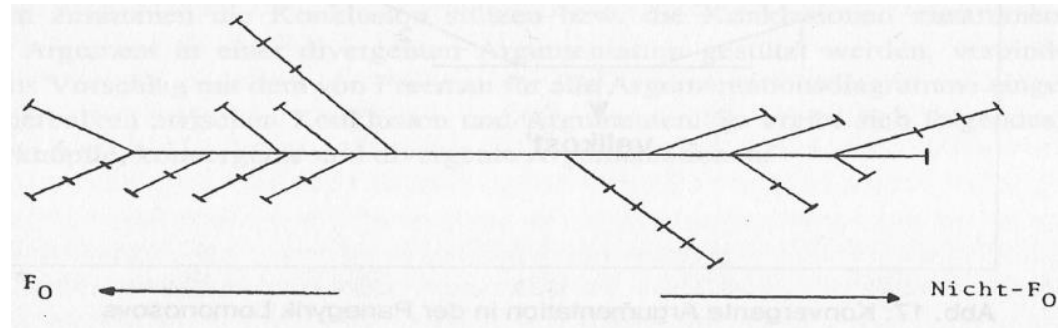


Discussions in which pro- and counter-arguments are provided are not necessarily aggressive, but they can be, and often are, even if they are not characterized by metaphors like those in Lakoff and Johnson's influential study. The first form of the intertwinedness of argumentation and aggression can be seen in the justification of aggression by argument. The second is when argumentation itself becomes an act of aggression. This is, for instance, the case when someone tends to destroy a consensus with the intention to destroy the social harmony of a community. Third, arguments can be intrinsically aggressive, for instance when they feature intentional fallacies, degrading nominations, demeaning predications, and suggestive claims that lead to hostility.

In the following study, I show how argumentation and aggression can be intertwined in aggressive communication. This intertwinedness can be seen not only in prosaic statements, but also in poetry and other creative forms, as well as in multimodal texts in which written text and visualization are related to each other. The study combines the development of a theory of the intertwinedness of aggression and argumentation with a case study of aggressive argumentation in the Russian-Ukrainian conflict. In any political and military conflict, in addition to the official political discourse, there are popular forms of argumentative and aggressive communication. Political poetry and unofficial maps are among such texts. In the present study, maps are investigated as multimodal arguments. The examples analyzed are taken from a number of Internet sites representing Russian nationalist, that is, clearly anti-Ukrainian, positions. Specifically, http://geopolitica.ru and http://stanislavs.org are in focus. Poeto-political texts illustrate clearly how aggression and argumentation can be intertwined in ways where aggression is openly expressed, justified, or more or less covered by seemingly friendly theses and reasons. The chosen examples are Anastasiia Dmytruk's poem "Nikogda my ne budem brat'iami" ("Never ever we will be brothers") and responses it has received. These texts are found on popular Russian sites such as http://stihi.ru, which articulate widespread opinions about the Ukrainian crisis and reasons related to it.

In multimodal texts, which have been widely investigated during the last decade (examples are Forceville, Klug and Stöckl, Kress, Kress and van Leeuwen, LeVin and Scollon, Morozova), the image can represent a word or an expression or it can be a metaphor. The written text can give the image a surprise meaning, and the meaning of the written text can be formulated in the context of the image. From the argumentation theory perspective, these interrelations can be seen as complex arguments in which written text and visualization correspond to each other as thesis, reason, and consequence (conclusion). This is the case in advertising as well as in special textual forms such as maps, which I investigate below. In what follows, I demonstrate how 
multimodal texts embody argument structures, using an example of political advertising related to the Crimean referendum in March 2014.

Before the Crimean referendum (March 16, 2014), an election poster outed the illegal and aggressive character of the annexation, as seen in Figure 2. It showed two maps of Crimea: on the left side the peninsula is coloured deeply red with a swastika on it covered by barbed wire. On the right-side Crimea has the colours of the Russian flag. The header of the poster contained the phrase "On March 16 we will choose either ... or," while the alternative conjunction or (Russ. ili), positioned at the bottom between the two pictures of Crimea, signifies "occupied by fascists" or "liberated by Russia."

Figure 2: Election poster for the Crimean referendum (March 16, 2014) ${ }^{2}$

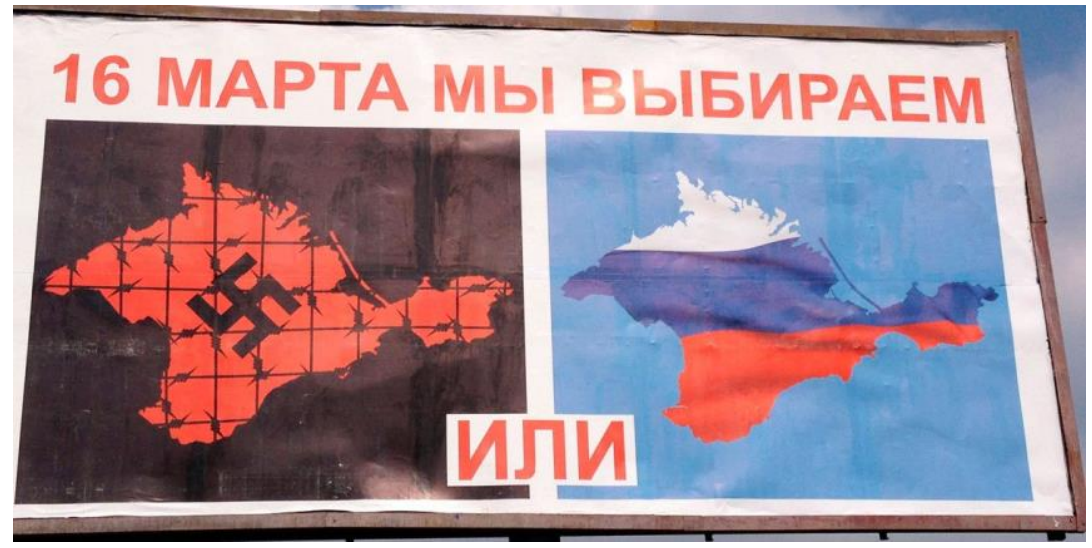

The Crimean election poster in Figure 2 is a clear example of an aggressive argument; here, two visualizations represent the thesis that a Ukrainian Crimea would be a fascist prison. This absurd allegation was nothing less than a crude defamation of Ukraine and all who did not support the connection of Crimea to Russia. But waste phrases and defamations do not constitute arguments. The poster displayed an argument because of its appellative intention. The alternative between fascism and Russia instead of Ukraine and Russia provided a simple reason to vote for Russia.

The propaganda displayed in Figure 2 did not remain without an answer. On the satirical site Politota, where one can find many political cartoons, memos, and comments, a satirical interpretation of the poster was

${ }^{2}$ https://pbs.twimg.com/media/C7AdqGsXEAEUFL2.jpg. Accessed 6 May 62018. 
published in 2014. In this particular figure, both maps of Crimea are in Russian colours and covered by swastika and barbed wire (Figure 3).

Figure 3: Manipulated election poster for the Crimean referendum (March 16, $2014^{3}$

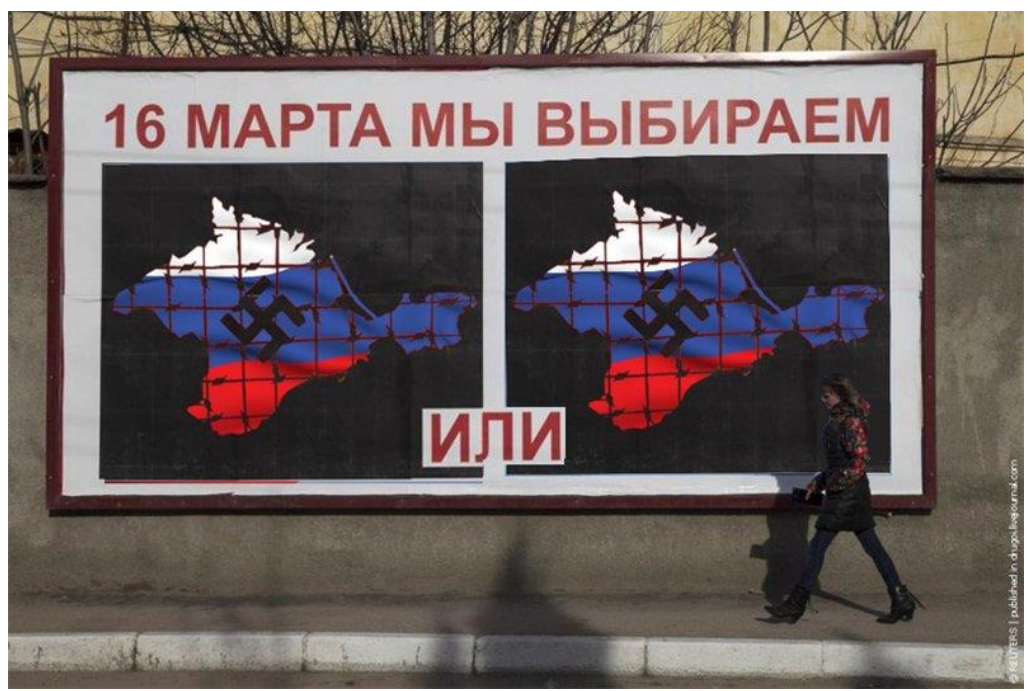

\section{THE ARGUMENTATION SCHEME}

In his 1972 book, Objective Knowledge: An Evolutionary Approach, philosopher Sir Raimund Karl Popper (1902-94) expanded the Organon model of his teacher Karl Bühler (1879-1963) with the argumentative function. In Bühler's model (1934), a distinction is drawn between the expressive function, the conative (i.e., appealing) function, and the representation function as the fundamental linguistic functions, the last of which can be found only in human communication and not in the communicative behaviour of animals (xxvi, 28-33). In contrast to the Organon model's representative function, which is descriptive and therefore features the idea of "truth (as distinct from falsity)," Popper saw the idea of "argumentative use of language, in critical discussion" in "validity (as distinct from invalidity)" (237). A representative claim achieves its goal, when it is understood and taken as true by its recipients, whereas an argument needs to be appreciated as being valid, i.e., it is distinguished by a valid reason as a

3 http://polit.reactor.cc/post/1221306. Accessed 6 May 2018. 
meaningful claim or appeal. In his extension of Bühler's model, Popper thought first about scientific argumentation and second about everyday communication. However, especially in current communication and in persuasive discourses, like politics, validity does not automatically imply that an argument will be convincing, and arguments that reach their goal to convince the audience are not always valid. On the one hand, reasons can be accepted, but nevertheless rejected due to counter-reasons which seem more substantial to an opponent. On the other hand, valid arguments should not contain fallacies, lies, defamation, slander, or libel, but as we see in the example of the Crimean election poster from 2014, these "forbidden" features are broadly used in propaganda and other kinds of persuasive communication, like political rhetoric or commercial advertising. Such differences in argumentation were already seen and described by Aristotle in his The Art of Rhetoric, where the logical form of syllogism is distinguished from the less strict enthymeme which Aristotle calls "rhetorical syllogism" (Book I, part 2; see also Kuße, Konjunktionale Koordination 324-28). In enthymemic arguments, premises can be valid, or better to say plausible, and therefore convincing to communication participants even if they do not conform to the strict criteria of validity, i.e., truthfulness of the given reason(s), rationality of the argument, and logical coherence between premises and conclusion(s). In the case of the Crimean election poster, the rhetorical force is based on the alternative structure with its unambiguous evaluation and historical allusions to World War II, where Ukrainian patriots, namely the so called Ukrainian Insurgent Army (UPA), temporarily collaborated with the German Nazi regime. This allusion could give the visualized argument not only plausibility for some recipients, but also could provoke hostile feelings of fear and anger against Ukrainians. As the ensuing referendum showed, such propagandistic argumentation was very effective. One could argue that the infamous poster does not contain any argument, but only brutal libel, and that it must be seen as a kind of visual hate speech, but such clear distinction of argument and non-argument seems to me too easy. In enthymemic rhetoric, where reasons are based on meanings rather than on knowledge, the border between legitimate plausibility and illegitimate manipulation is hard to ascertain.

In order for a complex statement to be called an argument, some formal elements are required, as Figure 4 illustrates. First, there has to be a question in dispute, a Quaestio, followed by a thesis to which the argument's conclusion should correspond. The thesis has to be supported by a reason that leads to the conclusion. The connection between reason and conclusion has to be distinguished with an inference-licensing rule (to borrow the term from Hitchcock 81-95) which makes a claim in favour of the conclusion reasonable. For instance, the inference-licensing rule of the Crimean poster (Figure 2) could be formulated as follows: "If we want to avoid fascism in 
Crimea, we have to vote for Russia." The question of whether the inferencelicensing rule is plausible, and the argument therefore becomes convincing, depends somewhat on the audience.

Figure 4: Quaestio-inference-licensing rule-scheme (Kuße, Kulturwissenschaftliche Linguistik 94; Kusse 98)

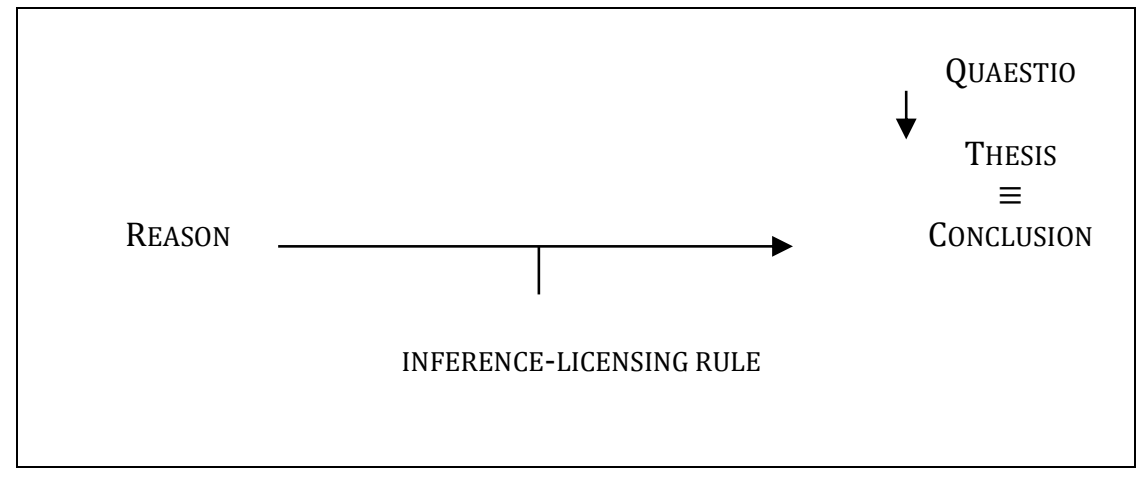

In addition to the relativity of their validity, enthymemic arguments are distinguished by a lack of completeness of all premises and conclusions. In everyday communication and in rhetorical persuasive argumentation, the thesis, the conclusion, or the reason can represent the entire argumentation, because the participants understand not the expressed information but the implied information, which makes the argument complete. In the argument of the Crimean poster, the reason to vote for the connection to Russia is provided by the thesis that otherwise Crimea would be occupied by fascists.

Aggressive argumentation like the Crimean poster in Figure 2 is performed by aggressive theses, but it can also be distinguished by aggressive reasons. In the following two sections, which represent the focus of the current study, the objectives are to demonstrate both the aggressive theses and the aggressive reasons. In section 3, I present examples for the thesis "Ukraine does not exist" which is often visualized by pseudo-political maps. In section 4, aggressive reasons for and counter-reasons against the thesis "Never ever we will be brothers" are demonstrated. This is the title of the poem mentioned above by Dmytruk, published on YouTube and Facebook in 2014. This poem generated a political poetry war with a multitude of aggressive reasons concerning the differences between Ukrainians and Russians, worthy of investigation. 


\section{AGGRESSIVE THESES}

Probably the most aggressive thesis within the Russian-Ukrainian conflict is the assertion that Ukraine does not really exist, and the contemporary Ukrainian state is a historical accident. Sometimes this thesis about the nonexistence of Ukraine is openly expressed, while at other times it is implicated in wider considerations about the fate and the future of Ukraine and its relations with other countries, mainly with Russia. Already in the 1990s, Russian ultranationalists such as Aleksandr Dugin and the right-wing clown in Russian politics, Vladimir Zhirinovskii, openly denied the right of Ukraine to exist as a sovereign state (cf. Uffelmann 265). In the Russian talk show Voskresnyi vecher s Vladimirom Solov'evym (Sunday Evening with Vladimir Solov'ev) on July 10, 2017, Zhirinovskii divided Ukraine in at least two pieces and added it to different geopolitical spheres: the north-west to the Western hemisphere, and the south to Russia, as depicted in Example 1 below:

Example 1: Результат я вижу один: северо-западная Украина пусть Львов, НАТО, ЕС, кто угодно. Юг-это наше от Донбасса до Тирасполя.

I see one result: the north-west of Ukraine be it Lvov, NATO, EU, whoever it is. The south-that's ours from the Donbass to Tiraspol. ${ }^{4}$

Zhirinovskii is known for his directness and for his lack of political respect and diplomatic prudence, as seen in Example 1. In contrast, Vladimir Putin provides similar ideas but in a more implicit and hidden manner. This is demonstrated in his speech on March 18, 2014, two days after the Crimean referendum. Consider Example 2:

Example 2: После революции большевики по разным соображениям, пусть Бог им будет судья, включили в состав Украинской союзной республики значительные территории исторического юга России. Это было сделано без учёта национального состава жителей, и сегодня это современный юго-восток Украины. (“Obrashchenie”)

After the revolution, the Bolsheviks, for a number of reasons - may God judge them - added large sections of the historical South of Russia to the Republic of Ukraine. This was done with no consideration for the ethnic make-up of the population, and today these areas form the South-East of Ukraine. ("Address")

In Example 2, the Russian president hinted that the contemporary borders of Ukraine do not correspond to the ethnic affiliation of its inhabitants because they are no more than the result of a hardly comprehensible

${ }^{4}$ Unless otherwise indicated, all translations are my own. 
administrative act during the post-revolutionary period in the twentieth century. The status quo of the Ukrainian state is implicitly marked as an evil, because even God is invoked by the speaker in view of the Bolsheviks' decision. A month later, in his TV show Priamaia liniia s Vladimirom Putinym (Direct Line with Vladimir Putin), the president repeated the unspoken thesis about the false borders using the colonial term "Novorossiia," from the time of Catherine II, to characterize the supposed original territorial ownership of the south-east of Ukraine ("Priamaia"). Using such terms and indicating them as historical information as Putin did, is not yet an open justification of a future invasion. The hidden rhetoric provides a thesis about the irregularity of the Ukrainian borders and presents for the large audience ready moral reasons to justify an annexation of nearly half of current Ukraine.

Nothing is easier to visualize than the fragmentation of a country. Especially in popular geopolitics, a map provides a simplified view of political geography in which an alternative political "reality" seems to be real (cf. Uffelmann; Dodds). The map expresses a thesis about what is the case, or what should be the case. On sites with anti-Ukrainian positions, numerous fictive maps circulate, on which Ukraine is reduced to a small territory or has even completely vanished. One thesis behind those maps is expressed in an English post on the site http://stanislavs.org (from Feb. 27, 2016). This post is titled "How Malorossiia Was Turned into the Patch-quilt of Discord That Is 'Ukraine.'" On the map illustrated in Figure 5, Ukraine is reduced to the territory of the Zaporozhian Cossacks in the middle of the seventeenth century. All other territories are indicated as being "added" in several periods, the last being "added" in 1954.

Figure 5: Map at http://stanislavs.org/category/ukraine-russia/page/2/ (Accessed 22 Mar. 2018)

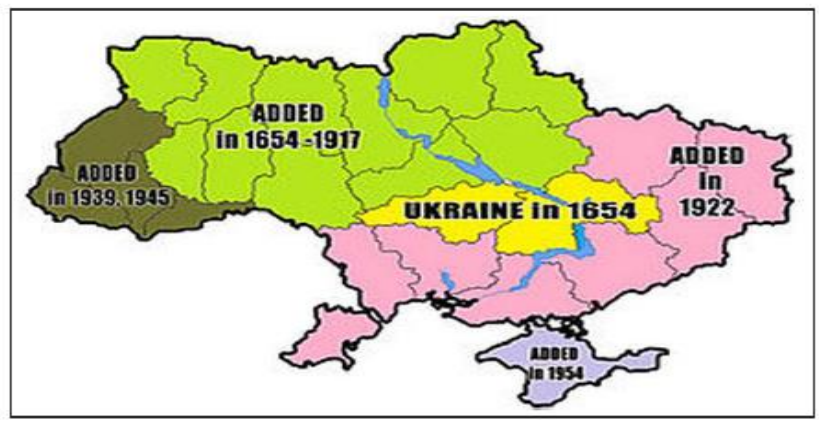


In Figure 5 the information about years and territories is not without historical background, but the changes of borders and the history of country unification is not specific for Ukraine (for instance, German history demonstrates a similar case of shifting borders and changing geopolitical situations). The map presents the aggressive thesis that there is no Ukraine except for a small yellow band left and right of the Dnipro. Therefore, important facts of Ukrainian history, such as the founding of the Ukrainian National Republic in 1917, are ignored. It is unclear what "added in 16541917 " could mean. Clearly, these questions are not of interest to the author, who openly expressed his intention to provide and prove a thesis of the nonexistence of an original Ukraine. He comments on his map as follows:

Example 3: This map shows how the size of Ukraine changed through history. NOTE! What is shown here in yellow as 'Ukraine in 1654' was in fact the territory of the Zaporozhie Cossacks (Zaporozhskie Kazaki). There was no country or territory called Ukraine before Lenin and Bolsheviks created the Ukrainian Soviet Socialist Republic as part of the USSR. ("How Malorossiia")

On other maps similar to the one in Figure 6, Ukraine is reduced to a minimum in the far west of the contemporary state (https://www.geopolitica.ru site, subtitled with the slogan "Carthago delanda est").

Figure 6: Map at https://www.geopolitica.ru/en/article/there-are-no-validarguments-against-liberation-novorossia (Accessed 5 Feb. 2018)

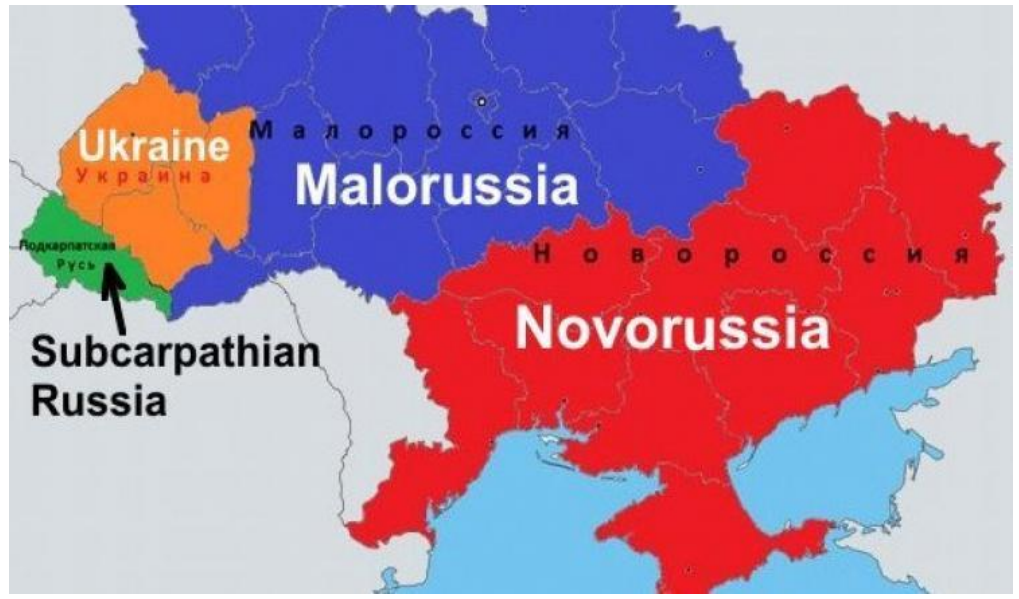


Using historical names like Malorussia (Малороссия) and Novorussia (Новороссия) and the misleading term Subcarpathian Russia (which does not indicate a territory of Russians but of the ethnic Rusyns), the map in Figure 6 again provides a thesis of the irregularity, if not the non-existence, of Ukraine. This thesis could be used as a reason to justify the annihilation of Ukraine by military force. A similar aim is voiced in the related article by Nicholas Nicholaides titled "There Are No Valid Arguments against a Liberation of Novorossia." The author combines the proposed country fragmentation with further political implications. The title entails the presumption that something like Novorossiia exists (and therefore Ukraine does not exist) and has to be liberated. It is then perhaps not surprising that the author calls the Ukrainian government the "Kiev Nazi junta," a group that supposedly occupied Novorossiia and should be kicked out of the country.

Another hostile example of political fragmentation in which Ukraine looks wider than it does in Figure 6, but is nevertheless separated from Novorossiia, is a map found on http://LiveJournal.com (Figure 7). It was placed on the website by a user with the nickname arcktick on March 15, 2014.

Figure 7: Map at https://arcktick.livejournal.com/15240.html (Accessed 21 Mar. 2018)

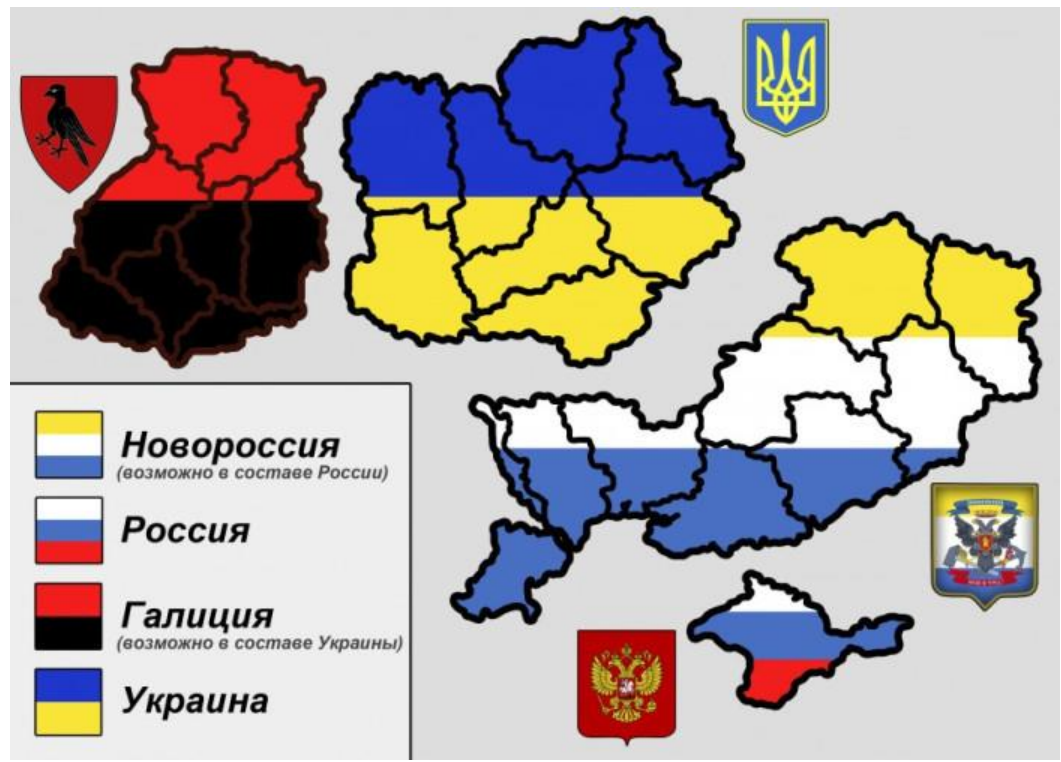


On the map in Figure 7, Crimea belongs to the Russian Federation. Novorossiia is an independent state, but on the legend it is written "possible within Russia." With respect to the separated state Galicia, the legend suggests "possible within Ukraine." Moreover, the colouring of Galicia does not match the colours of the historical flag of the Principality of GaliciaVolhynia (blue and yellow as in present day Ukraine), but is marked in the colours of the UPA, i.e., the Ukrainian Insurgent Army in World War II. The chosen emblem for Galicia is the Halych coat of arms that shows a jackdaw (or a raven). This signification of the fictive western Ukrainian state Galicia has some degrading implications. These implications can be found in a comment from another user of LiveJournal. On April 30, 2014, Stella VL commented about the Halych coat of arms in Example 4:

Example 4: You will laugh, but this is the emblem of Galicia! What kind of little small people are you, when on your emblem, you portray a crow (an angry one (-) (in Russian; see Figure 8).

Figure 8: Halych coat of arms at https://www.liveinternet,ru/users/2458238/post322966915 (Accessed 21 Mar. 2018)

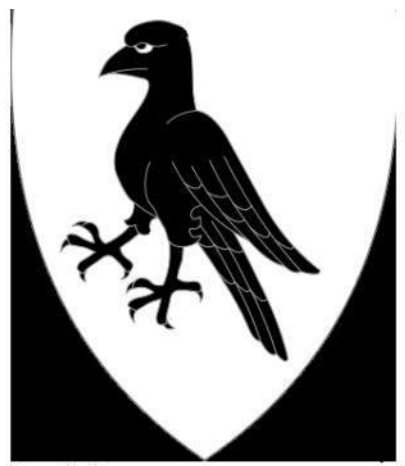

Вы будете смеяться,но это герб Галичины! Это каким надо быть народием что бы у себя на гербе изобразить ворону?

(злую:)

In Example 4 and Figure 8, the text represents an open hate speech attack. The image in Figure 8 is followed by some commentaries: "Они и живут, как вороньё," literally translated as: "They also live like swarms of crows," which metaphorically means "They are vultures." This accusation is 
connected to the renaissance of Stepan Bandera, the leader of the Ukrainian nationalists before and during World War II, who was convicted as a war criminal in Russia. In the commentary to Figure 8, not only Galicians, but Ukrainians supporting the Euromaidan are metaphorically accused of following "the gangs of Bandera": "the heads of the Bandera gang already begin to fly" ("начинают головы уже лететь бандеровской своры").

Ukraine is now not only fragmented geographically, but the regions are related to different political orientations, among which the west is created as a fascist space. This is already indicated by the colours of the UPA flag. It cannot be denied that in present Ukraine, especially in the western parts, there is a certain degree of nostalgia toward the UPA. Furthermore, as in other European countries, and not least in Russia, right-wing parties penetrate the political scene. However, there is an implied universal quantifier in a defamatory map (Figure 7). In understanding maps as multimodal texts, the colouring of Galicia can be interpreted as a statement that suggests that all Galicians support UPA-nostalgia or even the Right Sector (Pravyi Sektor).

The colouring of different parts of a map can be even more defamatory. On a map from the website http://stanislavs.org in Figure 9, Galicia is covered by the Nazi flag with the swastika.

Figure 9: Map at http://stanislavs.org/category/ukraine-russia/page/2/ (Accessed 22 Mar. 2018)

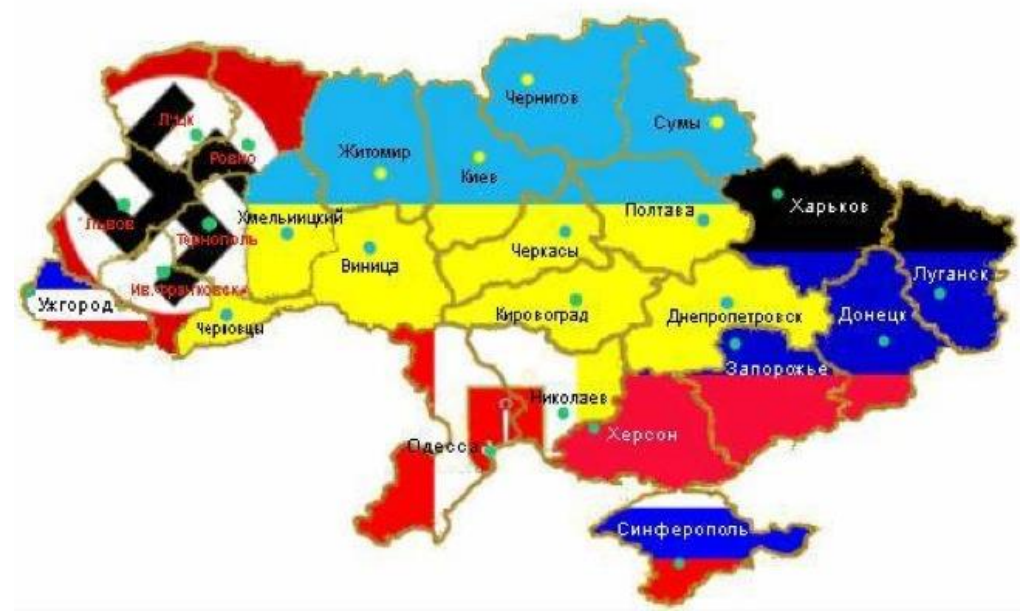


The accusation of fascism directly leads to the legitimation of war and suggests that the putative Ukrainian fascist is now seen anywhere in Ukraine. On the site http://e-news.su with the hashtag \#SaveDonbassPeopleFromKievNazisArmy, on February 9, 2015, the map shown in Figure 10 was posted. On this map, the fascist UPA-wolf is kicked out of Novorossiia by a military boot with the Russian flag on it. The slogan on the bottom says in Russian: "There is no place for Nazis in our country."

Figure 10: Map at http://www.e-news.su/in-ukraine/45935-za-chto-voyuetdonbass.html (Accessed 5 Feb. 2018)

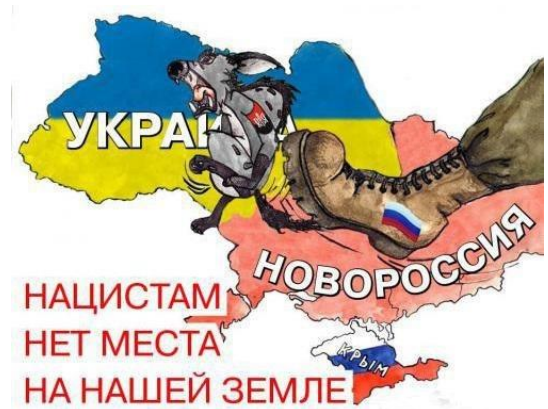

In Figure 10, the thesis of the non-existence of a real Ukraine in its contemporary borders is openly combined with the segregation of good and evil and the condemnation of Ukrainians as fascists or supporters of fascism. The indication that the boot is a Russian one demonstrates that the war in Donbass is not only a civil war, but rather a Russian-Ukrainian war.

As we see in Figures 5-10, the thesis "Ukraine does not exist" has variations. The first variant sees Ukraine as an artificial construct without a historical right to exist. Another variant looks at Ukraine as a territory occupied by fascists and in need of liberation. In both of these variants, the consequence is the annihilation of the contemporary Ukrainian state. This does not automatically mean that the authors of such suggestions deny all Ukrainian peculiarities. In the article "Za chto voiuet Donbass" by Eduard Birov (on the site http://www.e-news.su/), some folkloristic features are accepted, but the website suggests that Ukraine should be incorporated into the so-called "Russian world" ("russkii mir") without any political independence. The talk is about the geographic Ukraine, not the political Ukraine, the latter which should in the authors' perspectives no longer exist. 
Example 5: Географическая Украина, освобожденная от русофобской пропаганды, может и должна оставаться частью русского мира при определенном фольклорном региональном своеобразии. (Birov)

The geographic Ukraine, which is liberated from Russophobe propaganda, can and must remain as a part of the Russian world with some folkloristic regional peculiarities.

However, on other sites even the cultural specifics of Ukraine are denied. For instance, specifically radical hatred against Ukraine is provided in the following example:

Example 6: На Украине нет единого народа, отдельного от народа остальной Руси, он существует лишь в конституции, подразумевая формальное гражданство. (http://tribunalkrim.narod.ru/new/frankenshtein.htm. Accessed 22 Mar. 2018)

There are no united people in the [sic.] Ukraine, that is different from the other Rus'. It exists only in the constitution, in the understanding of a formal citizenship.

In Example 6, even the preposition "na" (on/in), normally used with regions and territories, instead of the preposition " $v$ " (in), used with countries, signifies a denial of Ukraine's status as a sovereign country and state, promoting Ukraine as a geographic region within an empire. Therefore, the signification is translated as "in the Ukraine." The author in Example 6 uses the historical term Rus' in the sense of "Russian world" but with an allusion to the Kyivan Rus' in the Middle Ages, in which indeed the difference between Ukrainians and Russians did not exist. On the site http://geopolitica.ru, a similar position is held. In this example, the statement is even more defaming:

Example 7: There is no "Ukrainian people." There are the fascists in the West and the Russians and Russian-speaking Ukrainians in Novorossia. (Nicholaides)

The maps in Figures 5-7 and 9-10 and the commentaries cited in Examples 3 and 5-7, imply the thesis that Ukraine does not exist by dividing the map of the contemporary state into historically and ideologically disconnected parts. The thesis can stand as a suggestion without further argumentation, but mostly it leads to reasons why such a thesis should be afforded. This is illustrated in the cited article "How Malorossia Was Turned into the Patch-quilt of Discord That Is 'Ukraine,"' where these reasons are performed as pseudo-historical critiques (see Figure 5, Example 3). However, in such texts, the arguments are circular for the most part. The 
various theses of the non-existence of Ukraine are provided through fictive political maps that represent the borders and the inner structure of the imagined fragmentation of the Ukrainian state. These maps fulfill a double function. They are visualizations of the thesis on the one hand, and a kind of proof of what Ukraine looks like, on the other. This is especially the case when the territories are related to political camps: to the putative fascism in the west and to the "Russian world" in the east.

The maps perform a circular argument in which the thesis is provided by the visualization and at the same time proved by it: "What you see on the map, is what you find in reality." This circularity works because of the performative power of maps. They not only represent political realities, they can provide such realities. Whether they do so, depends on the legal status of the person or institution responsible for the map. Like a performative speech act, a map reflects reality only when the producer wants it to and has the power to achieve this. Fictive maps can lead to conflict about the status of Ukraine, and more important, can be used as justification or even legitimation of civil war and Russian invasions. The underlying inferencelicensing rule of such justification is easy to formulate and can be very convincing. It can be expressed in the following conditional formula: "When a territory is occupied by fascists, it should be liberated." The author of the pamphlet "There Are No Valid Arguments against a Liberation of Novorossia" on http://geopolitica.ru (see Example 7 above) expresses this kind of argument quite bluntly when he rejects reasons against a Russian invasion in the so-called Novorossiia:

Example 8: "It is a trap to get Russia to war"-No! The trap is to fool Russia not to intervene, because if Russia intervenes the Kiev junta will fall and Russia and Novorossia will win quickly. So the trap is to scare Russia not to intervene. (Nicholaides)

The debate of Novorossiia and the maps dividing Ukraine into several parts arose after the Revolution of Dignity and during the annexation of Crimea, mostly in 2014. These events seem to be already historic-the project of Novorossiia failed, and a broader Russian invasion did not take place (about Novorossiia cf. Suslov). But the debate itself and the performance of aggressive theses through maps could be reactivated at any moment, as long as the Russian-Ukrainian conflict continues.

The conflict is related to Russian-Ukrainian relations and the ideologies that are constructed around them. One can see different perspectives of them: from hostility to brotherhood or even the assumption that Ukrainians and Russians should be seen as one people. The last position is the official standpoint of the Russian president Vladimir Putin, who several times in speeches and interviews underlined the close brotherhood and the unity of 
Ukrainians and Russians. In a long interview with Oliver Stone, Putin claimed that Ukrainians and Russians are nearly the same.

Example 9: Я уже много раз говорил и хочу повторить еще много раз: я глубоко убежден, что украинский и русский народ-близкие родственники, это практически одно и то же. Что касается языковых особенностей, культурных особенностей, исторических особенностей, это, безусловно, требует уважения и, кстати говоря, всегда уважалось в рамках единой страны. (Stoun 231)

On many occasions I've said that and I'd like to reiterate. I'm deeply convinced that the Ukrainian people and the Russian people are not simply close relatives. They are almost the same. As for the language, the culture, the history, each certainly has to be treated with respect. And even when we were one single country, we treated them with respect (Stone 192-93).

In Example 9, the seemingly friendly assertion of Russian-Ukrainian brotherhood shows Ukraine as a geographic space with some regional specificities, but not as a politically and culturally independent unity. In the following section, the aggressive reasoning in the political poetics of Dmytruk that reacts against the ideology of brotherhood and the responses of her opponents is analyzed.

\section{AGgRESSIVE REASONS}

A striking example of the accumulation of aggressive reasons in favour of an already aggressive thesis is the Russian-language poem "Nikogda my ne budem brat'iami" ("Never ever we will be brothers") by the young Ukrainian poetess Anastasiia Dmytruk, published on March 10, 2014, on her Facebook site and after that performed on YouTube. The thesis of the title is easy to understand as a rejection of the rhetoric of familiarity and brotherhood from the Russian side, namely from Putin. The poem is structured in antitheses with clear axiological distinctions. In this poem, portrayed in Example 10, Ukrainians are characterized as young, free, revolutionary, and democratically thinking people, whereas the Russians are accused of being totalitarian, frightened, unfree, and obsolete.

Example 10: Никогда мы не будем братьями!

Ни по родине, ни по матери.

Духа нет у вас быть свободными-

нам не стать с вами даже сводными. (Dmytruk) 
Never ever we will be brothers-

neither by motherland, nor by mothers.

You have no guts to be free

we won't even become step-siblings. ${ }^{5}$

Dmytruk's poem has a very clear structure. In Example 10, after the formulation of the thesis "Never ever we will be brothers-not by motherland, not by mothers," a cascade of antithetical reasons follows, Ukrainians being the "We" and Russians being the "You." These reasons have different contents, but the oppositions "good and bad" and "freedom and submission" are expressed or implied in every sentence. Furthermore, as Example 11 illustrates, the Russian side is accused not only of using a false metaphoric sense of brotherhood but also of pretending to be superior, i.e., of being the "big brother" in the Russian-Ukrainian relationship.

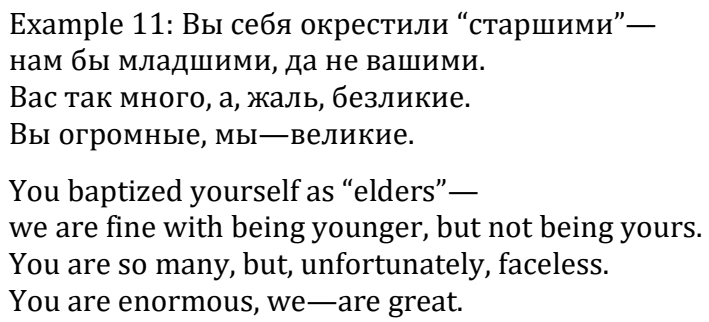

The following verses in Example 12 illustrate the stereotyped worldview of Dmytruk's poem expressed in polar values. Silence, tsarism, and submission are the main values of Russians, whereas Ukrainians are ready for an uprising, for supporting democracy, and do not fear even Molotov cocktails.

Example 12: У вас дома "молчанье-золото,"

а у нас жгут коктейли Молотова,

да, у нас в сердце кровь горячая,

что ж вы нам за "родня" незрячая?

$[\ldots]$

Вам шлют новые указания-

а у нас тут огни восстания.

У вас Царь, у нас-Демократия.

Никогда мы не будем братьями.

At your home, "silence is golden,"

At our home, Molotov cocktails are being burnt.

Indeed, the blood is hot in our hearts,

5 My translation. See also the translation by Andrey Kneller at https://www.facebook.com/knellera/posts/290782174430944 (Accessed 17 Aug. 2018). 
what kind of blind relatives are you to us?

$[\ldots]$

You are being sent new orders,

and we have the flames of uprising here.

You have the Tsar, we have Democracy.

Never ever we will be brothers.

The unambiguous polarized oppositions with their hostility against all who do not belong to the We-group, i.e., to the supporters of the Euromaidan, provoked responses that are no less aggressive. In a very short time a "viral poeto-political discourse" ("ein viraler poetopolitischer Diskurs") arose (Stahl 444). On http://stihi.ru, directly after Dmytruk's "Never ever we will be brothers," a poem followed, entitled "We Are not Brothers of Bandera Mugs" ("My ne brat'ia banderovskim rozham").

\section{Example 13: МЫ НЕ БРАТЬЯ БАНДЕРОВСКИМ РОЖАМ}

(Песня. Автор и исполнитель в ролике не указаны)

Мы не братья бандеровским рожам,

мы не братья убийцам людей,

чьи дела и поступки безбожны,

кто носитель фашистских идей. [...]

(https://www.stihi.ru/2015/11/09/4971) (Accessed 10 Dec. 2017)

\section{WE ARE NO BROTHERS OF BANDERA MUGS}

(Song. Author and performer are not named in the clip.)

We are not brothers of Bandera mugs,

We are not brothers of assassins,

Whose acts and behaviour are godless,

Who are carriers of fascist ideas.

This poetic answer can be characterized as a negative agreement, which means that the thesis of Dmytruk's initial poem is accepted, but the reasons Dmytruk gave are rejected and opposed by contrary reasons. The negative agreement can be paraphrased as follows: "I agree with the thesis, but the reasons are faulty and should be replaced by axiological contradictory theses." In his poem "Otvet ukrainskoi devochke Naste Dmitruk na ee stikhi 'Nikogda my ne budem brat'iami"” "'Answer to the Ukrainian Girl Nastia Dmytruk and Her Poem 'Never ever we will be brothers"'), Iurii Loza, a Russian singer and song writer accuses Dmytruk and her followers of having no inner family relations. Again, Ukrainians are accused of being fascists, even from birth. As Example 14 demonstrates, there is a negative agreement with Dmytruk's thesis.

Example 14: Вас растили, наверное, не матери, И не с сестрами, и не с братьями, 
Вам фашистскую, черную свастику

При рождении дарили каратели.

С детства вам забивали головы

Профашистскими "супер-героями,"

Вот и жжете коктейли вы Молотова,

А не учите Правду истории... ("Stikh-otvet")

You, probably, weren't raised by mothers,

You grew up with no sisters, nor brothers.

A fascist black swastika

The punishers gave to you at your birth.

Since birth they hammered into your heads

Pro-fascist "super heroes."

Thus you burn Molotov cocktails

And do not study the Truth of history...

The next accusation and argument-why Dmytruk's reasons should be recognized as faulty, although the thesis is right-belongs to a negative stereotype of Ukrainians that has persisted since the time of Ivan Mazepa (1639-1709) and his rebellion against Peter I (see Kappeler 63-66). As illustrated in Example 15, this negative stereotype is: Ukrainians are traitors.

Example 15: Вы давно свои земли продали!

Вы и предков своих тупо предали. ("Stikh-otvet")

Long ago you sold your lands!

And you stupidly have betrayed your ancestors.

The accusation in Example 15 is related to the dignity of the Soviet veterans of World War II who were allegedly betrayed by the Euromaidan. After the accusation of betrayal illustrated in Example 15, other allegations are attested. These are that supporters of the Maidan actually do not love Ukraine, and they are not real Ukrainians by blood. They are Nazis and consequently cannot be brothers to the writer's We-Group. Example 16 is another clear illustration of such negative agreement.

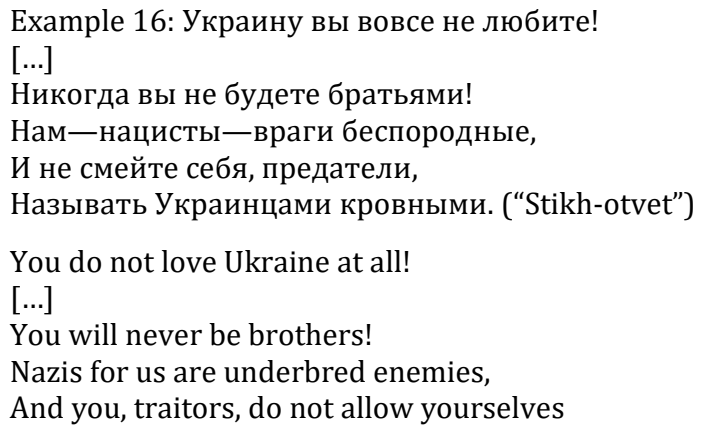


To be called native Ukrainians by blood.

Here, similarly to the maps that divide Ukraine into several parts with fascists in the west and Novorussians in the east (as shown in Figures 5-7 and 9-10 above), the Ukrainians are distributed into good Ukrainians and bad Ukrainians or real Ukrainians and fake Ukrainians.

By the opposition of a real and good Ukraine and a bad and wrong one, the negative agreement with Dmytruk can be directly formulated in the manner of the fictive political maps (Figures 5-7 and 9-10). One author, Roman Dikusar, who is currently a chairman of the youth parliament of Sevastopol, uses the opposition in his response "Brat'ia navsegda" ("Brothers Forever"). In contrast to previous examples, he does not formulate a negative agreement, but directly disagrees with Dmytruk, as shown in Example 17 below:

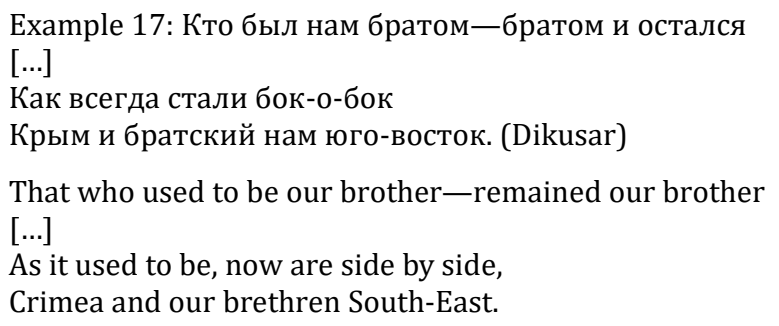

Iurii Efremenko, an important member of Molodaia Gvardiia (The Young Guard), the youth organization of the party Edinaia Rossia (United Russia), shot a YouTube video with the title "Sevastopol'skii otvet na stikh 'Nikogda my ne budem brat'iami'” ("Sevastopol's Response to the Poem 'Never ever we will be brothers'”). Consider Example 18:

\footnotetext{
Example 18: Мы всегда с вами будем братьями

И по родине, и по матери. (Efremenko)

We will always be brothers

By both, the fatherland and the mother.
}

In Example 18, the disagreement with Dmytruk's thesis is formulated directly: "We will always be brothers." The negation "ni ... ni" (neither [a]..., nor [b]) in Example 10 presented above, is now rendered by the double confirmation in the Russian syntactic construction " $i$... I" (both, [a]... and [b]).

Another author, Anna Gaidukova, similarly argues that "We," i.e., Ukrainians and Russians, will be brothers forever. She manages an Internet shop entitled "Nostal'giia" ("Nostalgia"), where she offers woollen dresses of 
her own production. The poem is posted on http://www.liveinternet.ru. Consider Example 19:

\author{
Example 19: Да навеки мы будем братьями, \\ И по Родине и по Матери, \\ И по Батюшке и по разуму [...] (Gaidukova) \\ We will always be brothers, indeed, \\ By both, the Motherland and by Mother, \\ By Father, and by Wisdom [...]
}

The poem is characterized by some pathetic and archaic, namely church Slavonic, forms. These are the beginning of the verse with " $d a$ " (which can be translated into "yes," but is rather a pathetic introducing particle), "naveki" (forever) and the expression "batiushka" which should be translated as "father," but means in a narrow sense "priest." As shown in Example 20, the poem culminates in an emphatic appeal for unity in an attempt to reach a sense of invincibility.

\title{
Example 20: Наши крови и судьбы единые, МЫ в ЕДИНСТВЕ НЕПОБЕДИМЫЕ!!! (Gaidukova) \\ Our bloods and destinies are one, In UNITY WE ARE INVINCIBLE!!!
}

In Example 20, the author displays her strong conviction that Russians and Ukrainians have close ties as "brothers" along many angles. Example 20 demonstrates the importance of the value of unity as a reason for disagreeing with Dmytruk. The choice of capital letters, as well as the three exclamation marks strengthen this reason. Additionally, the already cited poem by Dikusar implores for the unity of Ukrainians and Russians, which is demonstrated in Example 21:

\footnotetext{
Example 21: Много нас на земле родимой, сто народов в семье единой, в чём-то разные, чем-то похожи, нас никто разделить не может! В чём завидовать вам, несчастным? Вы-осколок страны прекрасной самый красивый и дорогойсейчас с протянутой рукой.
}

There are many of us in our dear land, Hundred of peoples united in a single family, Differing in certain things, similar in certain ways, No one can divide us! Why should we be jealous of you, the unfortunate people? 
You are the splinter of a wonderful country,

That is the most beautiful and dear,

But now is like a beggar.

In Example 21, Dikusar formulates his disagreement with Dmytruk's thesis and gives some circular reasons in the following way: "We are united because no one can divide us" and vice versa. All others who do not want to join the brotherhood are seen as the starving beggars of a formerly beautiful country.

There is a third type of response, which is between negative agreement and disagreement. This is the positive-negative agreement, in which the opponent agrees with both the thesis and the reasons, but s/he evaluates the reasons in a different, mostly contradictory way. Example 22 illustrates the argument:

Example 22: Да, у нас дома "молчание-золото,"

Для чего нам смеси убийства,一молотова?

Когда надо у нас душа горячая,

А сегодня, за Вас, плачем мы.

Ненавижу я эту братию

Что именует себя демократией

У “царя" без жертв все обходится,

А у вас? На каждого пуля находится! (Efremenko)

Yes, at our homes silence is golden

Why do we need any murder substances-Molotov cocktails?

When it is needed, our soul is spirited,

But today, we are crying for You.

I hate this brotherhood,

that entitles itself democracy.

Under the "tsar," all goes on without victims.

And what do you have? There is a bullet for everyone.

In Example 22, the positively connoted Molotov cocktail in Dmytruk's poem is taken by Efremenko as a sign of chaos and destruction. It serves as proof for the widespread meaning that the Maidan was an eruption of madness. In this frame, "tsarism" is presented as a guarantee for peace. This is in contrast to the negative connotation of "tsarism" in the earlier Example 10.

Example 23 is another instance of positive-negative agreement in response to Dmytruk, in which "tsarism" is positively evaluated:

Example 23: Лучше с Царем, чем с Псевдодемократией. (Dikusar)

It is better with the Tsar than with Pseudo-democracy.

Relatively, Dikusar agrees with Dmytruk's claim "You baptized yourself as the elders" (“Вы себя окрестили старшими”), but as Example 24 shows, 
Dikusar sees this status of the elder, or the big brother, as a positive value, obtained not from one's self but from history:

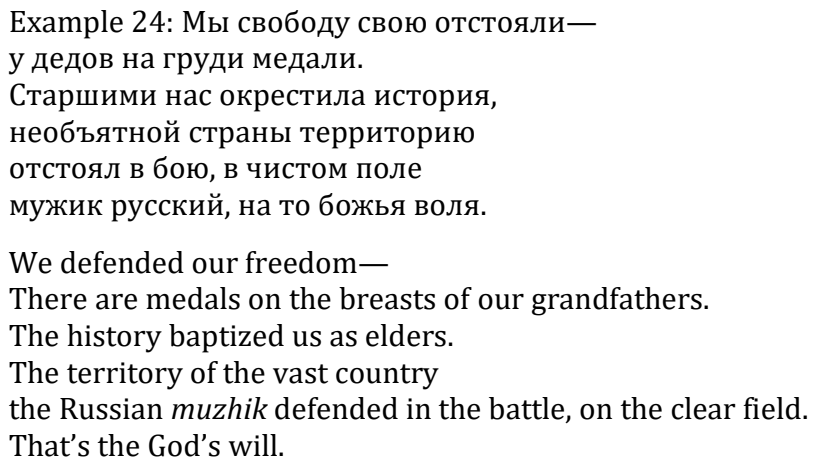

In Example 24 the author creates a heroic image of the past, namely the victory in World War II, and focuses on the concept of the strong fellow ("muzhik") as a Russian ideal. Thereby he performs a positive-negative agreement with Dmytruk's thesis that there is no brotherhood between Ukrainians, i.e., supporters of the Maidan, and Russians. In his poetical arguing, the reason lies in entirely different ideals and values, but what is negatively evaluated in Dmytruk's hymn to the Maidan is now evaluated as a positive ideal.

There are mainly three types of argumentative responses to Dmytruk: the negative agreement, the disagreement, and the positive-negative agreement. In all forms, one particular reason appears. This reason suggests the division of Ukraine into antagonistic and axiological polar mental spaces. There is the "good Ukraine" on one side and the "bad Ukraine" on the other. A very clear distinction in this manner is articulated in the poem by Gaidukova:

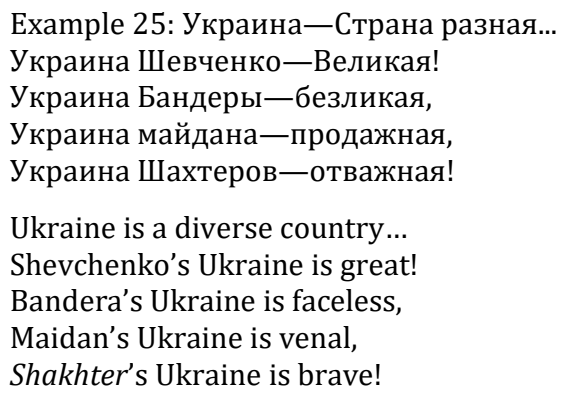

In Example 25, the good Ukraine is opposed to the bad Ukraine (in Gaidukova's view). The name of the famous nineteenth-century Ukrainian 
writer, Taras Shevchenko, stands for the good Ukraine. The name of Bandera represents the bad Ukraine. Bad is also the Maidan Ukraine, in contrast to the Donbas, the home of the "shakhters," which literarily means "miners," representing the concept of strong fellows. Through these oppositions the author creates a specific type of enemy, a type that could be observed in other examples and semiotic forms. In the present study, these enemies were particularly visible in the maps analyzed above. The enemy is often a stranger, because estrangement easily leads to uncertainty and anxiety (cf. Marchenko and Kurbatov). But in the Russian-Ukrainian conflict and the inner Ukrainian antagonisms, the enemy is not the stranger. On the basis of the ideology of brotherhood, and as a result of dividing the world into at least two antagonistic camps, the West and the East, the enemy on the fictive political maps, in official political communication and no less in political poetry, is the brother who wants to live and exist separately, who follows his own ideas and the like. The thesis "not with me" is automatically understood as "against me." Such a thesis most likely constitutes the essence of the conflict, which is directly connected to a fear of plurality. In eastern European countries, and others, this plurality has arisen around the last decade.

\section{CONCLUSION}

Using various texts tied to the Russian-Ukrainian conflict, the study shows how aggression and argumentation can be intertwined. The intertwinedness begins with an argumentation thesis, which is followed by aggressive reasons. In the Russian-Ukrainian conflict, aggressive arguments are provided in several semiotic forms-not only in official political communication, but also in the drawing of political maps in the frame of popular geopolitics, as well as in poetry. Furthermore, varieties of the realization of the inference-rule licensing scheme in Figure 4 have been shown. Theses sometimes represent an already implicit argumentation scheme, but there are also arguments in which reasons are explicitly given and the thesis is sometimes expressed, sometimes presumed. This is the case in the poeto-political war that was provoked by Dmytruk's poem "Never ever we will be brothers." The poetic responses can be classified as negative agreement, disagreement, and positive-negative agreement. What most of the responses to Dmytruk and the presented unofficial maps have in common is a special way of "making enemies." The enemy is not the stranger, but the other who wants to be the other. 
Works Cited

"Address by President of the Russian Federation." President of Russia, 18 Mar. 2014, http://en.kremlin.ru/events/president/news/20603. Accessed 10 July 2017.

"Argumentation." Vocabulary.com Dictionary, https://www.vocabulary.com/dictionary/argumentation. Accessed 6 Sept. 2018.

Aristotle. The Art of Rhetoric. Translation and index by W. Rhys Roberts, Megaphone eBooks, 2008. http://www.wendelberger.com/downloads/Aristotle Rhetoric.pdf. Accessed 7 Sept. 2018.

Birov, Eduard. "Za chto voiuet Donbass." E-news, 9 Feb. 2015, http://www.enews.su/in-ukraine/45935-za-chto-voyuet-donbass.html. Accessed 5 Feb. 2018.

Bühler, Karl. Sprachtheorie: Die Darstellungsfunktion der Sprache. G. Fischer, 1934.

Dikusar, "Brat'ia navsegda." Stikhi.ru, http://www.stihi.ru/2016/10/02/4553. Accessed 26 Mar. 2018.

Dmytruk, Anastasiia. "Nikogda my ne budem brat'iami." Facebook, 10 Mar. 2014, https://www.facebook.com/anastasiyadmytruk/. Accessed 10 Aug. 2018.

---. "Nikogda my ne budem brat'iami." YouTube, 19 Mar. 2014, https://www.youtube.com/watch?v=Qv97YeC563Y. Accessed 8 Sept. 2018.

Dodds, Klaus. Geopolitics: A Very Short Introduction. Oxford UP, 2007.

Efremenko, Iurii. "Sevastopol'skii otvet na stikh 'Nikogda my ne budem brat'iami."” YouTube, 19 Apr. 2014, http://www.youtube.com/watch?v=2INmW5-ugkk. Accessed 26 Mar. 2018.

Forceville, Charles J. Multimodal Metaphor. De Gruyter, 2009.

---. "Pictorial and Multimodal Metaphor." Handbuch Sprache im multimodalen Kontext, edited by Nina-Maria Klug and Hartmut Stöckl, De Gruyter, 2016, pp. 241-60.

Gaidukova, Anna. "Moi otvetna stikhi Nasti Dmitruk 'Nikogda my ne budem brat'iami."” $\quad$ LiveInternet, $21 \quad$ Apr. https://www.liveinternet.ru/users/4110034/post321935781/. Accessed 26 Mar. 2018.

Hitchcock, David. On Reasoning and Argument: Essays in Informal Logic and on Critical Thinking. Springer International Publishing, 2017.

"How Malorossiia Was Turned into the Patch-quilt of Discord That Is 'Ukraine."” Nemo's Realms, 27 Feb. 2016, http://stanislavs.org/category/ukrainerussia/page/2/. Accessed 22 Mar. 2018.

Kappeler, Andreas. Ungleiche Brüder. Russen und Ukrainer. Vom Mittelalter zur Gegenwart. C.H. Beck, 2017.

Klug, Nina-Maria, and Hartmut Stöckl, editors. Handbuch Sprache im multimodalen Kontext. De Gruyter, 2016.

Kress, Gunther. Multimodality: A Social Semiotic Approach to Contemporary Communication. Routledge, 2010.

Kress, Gunther, and Theo Van Leeuwen. Multimodal Discourse: The Modes and Media of Contemporary Communication. Bloomsbury Academic, 2001. 
Kuße, Holger. Konjunktionale Koordination in Predigten und politischen Reden. Dargestellt an Belegen aus dem Russischen. Otto Sagner, 1998.

---. Kulturwissenschaftliche Linguistik. Eine Einführung. Vandenhoeck \& Ruprecht, 2012.

Kusse, Khol'ger. Kul'turovedcheskaia lingvistika: Vvedenie. Izdatel'stvo Kazanskogo Universiteta, 2016.

Lakoff, George, and Mark Johnson. Metaphors We Live by. U of Chicago P, 1980.

LeVine, Philip, and Ron Scollon, editors. Discourse \& Technology: Multimodal Discourse Analysis. Georgetown UP, 2004.

Marchenko, Alla, and Sergiy Kurbatov. "Constructing the Enemy-Other in Social Media: Facebook as a Particular 'Battlefield' during the Ukrainian Crisis." Eurasia 2.0. Russian Geopolitics in the Age of New Media, edited by Mark Bassin and Mikhail Suslov, 2016, pp. 225-45.

Morozova, Olena. "Monomodal and Multimodal Instantiations of Conceptual Metaphors of Brexit." Lege artis: Language Yesterday, Today, Tomorrow. The Journal of University of SS Cyril and Methodius in Trnava, vol. II, no. 2, De Gruyter Open, Dec. 2017, pp. 250-83. DOI: 10.1515/lart-2017-0017 ISSN 2453-8035

Naess, Arne. Kommunikation und Argumentation. Eine Einführung in die angewandte Semantik. Translated by Armin von Stechow, Scriptor Verlag, 1975.

Nicholaides, Nicholas. "There Are No Valid Arguments against a Liberation of Novorossia." Geopolitika.ru, $10 \quad$ Jan. 2018, https://www.geopolitica.ru/en/article/there-are-no-valid-arguments-againstliberation-novorossia. Accessed 5 Feb. 2018.

“Obrashchenie Prezidenta Rossiiskoi Federatsii." Prezident Rossii, 18 Mar. 2014, http://kremlin.ru/events/president/news/20603. Accessed 10 July 2017.

Popper, Sir Raimund Karl. Objective Knowledge: An Evolutionary Approach. Clarendon Press / Oxford UP, 1972.

"Priamaia liniia s Vladimirom Putinym." Prezident Rossii, 17 Apr. 2014, http://kremlin.ru/events/president/news/20796. Accessed 22 Mar. 2018.

Stahl, Henrieke. "Poesie als politische Partizipation: Der virale poetologische Diskurs um Anastasija Dmitruks Videogedicht 'Nikogda my ne budem brat'jami' auf YouTube." Zeitschrift für Slavische Philologie, vol. 71, 2015, pp. 441-77.

"Stikh-otvet Iuria Lozy." LiveInternet, 14 Aug. 2015, https://www.liveinternet.ru/users/5358879/post321210249/. Accessed 26 Mar. 2018.

Stone, Oliver. The Putin Interviews: Oliver Stone Interviews Vladimir Putin. Skyhorse Publishing, 2017.

Stoun (Stone), Oliver. Interv'iu s Vladimirom Putinym. Al'pina Publisher, 2017.

Suslov, Mikhail. "The Production of 'Novorossiya:' A Territorial Brand in Public Debates.” Europe-Asia Studies, vol. 69, 2017, pp. 202-21.

Uffelmann, Dirk. "The Imagined Geolinguistics of Ukraine." Eurasia 2.0. Russian Geopolitics in the Age of New Media, edited by Mark Bassin and Mikhail Suslov, Lexington Books, 2016, pp. 249-73.

van Eemeren, Frans H., et al. Reconstructing Argumentative Discourse. The U of Alabama P, 1993. 